\title{
The consumption of rye bread and white bread as dimensions of health lifestyles in Finland
}

\author{
Ritva Prättälä ${ }^{1, *}$, Ville Helasoja ${ }^{1}$ and Hannu Mykkänen ${ }^{2}$ \\ ${ }^{1}$ National Public Health Institute (KTL), Department of Epidemiology and Health Promotion, Mannerheimintie 166, \\ FIN-00300 Helsinki, Finland: 'University of Kuopio, Department of Clinical Nutrition, PO Box 6, 70211 Kuopio, \\ Finland
}

Submitted 19 March 2000: Accepted 27 November 2000

\begin{abstract}
Objective: The aim of this research was to describe the variation in bread consumption within social classes and to link this consumption to health-related lifestyles in Finland from 1978 until 1998.

Design: A cross-sectional survey on health-related behaviour and socio-demographic factors has been conducted annually since 1978 .

Setting: Mailed questionnaire.

Subjects: A random sample of 5000 Finns aged 15-64 years has been drawn annually. The response rate has varied from $84 \%$ to $68 \%$.

Results: The consumption of rye bread decreased, but among the female population a slight increase appeared in the 1990s. The consumption of rye bread was associated with a low educational level and a rural place of residence. White bread was consumed less than was rye bread. White bread was consumed more frequently by the less educated in urban areas. Contrary to white bread, the consumption of rye bread was not associated with smoking, exercise or alcohol consumption.

Conclusions: The traditional place of rye bread in the Finnish dietary pattern has remained rather constant. White bread consumption has been associated with an unhealthy lifestyle. As a result, those Finns who are concerned about their health avoid white bread but seem not to associate rye bread with a healthier lifestyle. In Finland, rye bread has a different image to the image of whole-grain or dark brown bread in many other western European countries.
\end{abstract}

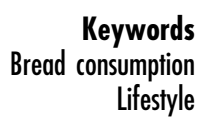

Rye is commonly consumed in northern and eastern Europe. Its energy and macronutrient content are similar to those of other cereals. However, rye is mostly consumed as whole-grain bread and therefore provides a considerable amount of dietary fibre. Greater intake of foods rich in fibre is associated with a reduced risk of coronary heart disease ${ }^{1}$ and some forms of cancer $^{2,3}$.

Rye products are the most important source of dietary fibre in Finland, accounting for almost $45 \%$ of the daily fibre intake for males $\left(23 \mathrm{~g} \mathrm{day}^{-1}\right)$ and $36 \%$ for females (18 $\mathrm{g} \mathrm{day}^{-1}$ ). By contrast, the contribution of wheat products is $17 \%$. Most rye is eaten as bread. In 1997, Finnish men ate on average $111 \mathrm{~g}$ of rye bread daily, and women ate $65 \mathrm{~g}$. The consumption of wholegrain wheat bread was $45 \mathrm{~g}$ and $40 \mathrm{~g}$, respectively, and that of white bread, $14 \mathrm{~g}$ and $8 \mathrm{~g}$. The overall consumption of wheat products was, however, higher than that of rye products ${ }^{4}$.

In many European countries, the higher social classes more often prefer whole-grain and brown bread to white bread $^{5-7}$. Total bread consumption is nevertheless often associated with low socio-economic status ${ }^{5,8,9}$.

In Finland, the higher social classes seem not to follow the European pattern of preferring brown and wholegrain bread. For instance, in 1992, the lower educational groups in Finland consumed more rye products, but no socio-economic differences emerged in the consumption of wheat ${ }^{10}$. On the contrary, the higher social classes in Finland prefer modern foods, such as fruits and vegetables, cheeses and sweets, whereas the lower classes more often eat traditional foods such as potatoes, (rye) bread, butter and high-fat milk products ${ }^{8,11}$.

As for other aspects of lifestyles, such as smoking and exercise, the higher social groups are the first to adapt to health-oriented and/or modern lifestyles. One noticeable exception to this pattern is alcohol, mainly because the higher social classes consume alcohol more frequently, $6,12-14$. 
Even if rye products still play a central role in the Finnish diet, rye was much more important at the turn of the century. According to consumption statistics, in 1900 Finns consumed on average $457 \mathrm{~g}$ of rye and $61 \mathrm{~g}$ of wheat products daily ${ }^{15}$. The Second World War led to food shortages, and both rye and wheat flour were rationed in 1941-1946. The rye rations were higher than were the wheat rations. In 1943, when the shortage was most severe, the daily wheat ration dropped to $16 \mathrm{~g} \mathrm{day}^{-1}$ whereas the rye ration increased ${ }^{16}$ from $182 \mathrm{~g}$ to $241 \mathrm{~g}$ day $^{-1}$. After the Second World War, rye consumption decreased. Whereas wheat consumption increased initially, since 1957 it has decreased ${ }^{15}$. In 1997 wheat consumption was $126 \mathrm{~g} \mathrm{day}^{-1}$ and rye consumption only one-tenth of the level in $1900^{17}, 43 \mathrm{~g}$ day $^{-1}$.

The use of white and rye bread has varied in Finland, not only by time and socio-economic status, but also by the region of residence. Rye bread consumption has been consistently higher in rural eastern Finland than in the urban areas of the south and southwest ${ }^{4,18,19}$.

Finnish rye bread has been associated with a rural place of residence and food shortage, whereas white bread has been a luxury. However, the recent discussion on functional foods and on the high fibre content of rye may have changed the traditional image of rye bread. As a result, rye bread may have become a fashionable product associated with high socio-economic status and healthoriented lifestyles.

The aim of this study was to describe the variation in bread use by social class and health-related lifestyles among Finnish adults in 1978-1998. Differences were analysed between age, educational and urban groups, and the association of bread consumption with smoking, physical activity and use of alcohol and vegetables.

\section{Material and methods}

The study material was the AVTK (Aikuisväestön terveyskäyttäytyminen/Health Behaviour among Finnish Adult Population) survey on health behaviour in Finland. The data have been collected annually since 1978 . Each year a random sample of Finns aged 15-64 years has been drawn from the national population register maintained by Statistics Finland. The register contains information on the education, income, place of residence, etc. of every Finnish citizen. The annual sample size of the AVTK study has been 5000 . The response rate has varied between $84 \%$ and 68\%. Differences between official census data and AVTK samples have been small, about $1-5 \%$ in most age and educational categories. According to non-response analysis on the AVTK data, from the year 1978 to $1994^{20}$, the effect of non-response on the age, educational or regional structure of the material is very small. However, groups with most risky health behaviours, like alcoholics and drug abusers, are not well covered in our data. Therefore, the proportions of people with 'unhealthy'
Table 1 Characteristics of material; values in \% except for total

\begin{tabular}{lrr}
\hline & Men & Women \\
\hline Total, $N$ & 39,773 & 42,765 \\
Study period & & \\
$1978-84$ & 39 & 36 \\
$1985-89$ & 23 & 24 \\
$1990-94$ & 22 & 23 \\
$1995-98$ & 17 & 18 \\
Age group & & \\
$20-34$ years & 36 & 35 \\
$35-49$ years & 36 & 35 \\
$50-64$ years & 28 & 30 \\
Education group & & 40 \\
$0-9$ years & 44 & 30 \\
$10-12$ years & 31 & 30 \\
13+ years & 25 & \\
Place of residence & & 22 \\
Capital region & 15 & 24 \\
Cities & 20 & 37 \\
Towns & 24 & \\
Rural & 41 & \\
\hline
\end{tabular}

habits in this study are probably smaller than in the source population.

Characteristics of the respondents are described in Table 1, which shows the socio-demographic factors of this study: gender, age, educational level and place of residence. According to previous studies ${ }^{4,10,19}$, these background variables have been associated with bread consumption. Educational level was measured as years of education and classified into three groups: 0-9, 10-12 and $13+$ years. The variable 'place of residence' referred to the degree of urbanisation: capital region, cities ( $>40,000$ inhabitants), towns $(<40,000$ inhabitants $)$ and rural communities.

The details of the AVTK survey have been presented earlier $^{21}$. The layout and main content of the AVTK questionnaire have been repeated in a similar form each year. The questionnaires have included 20-30 questions annually on food habits. Bread consumption has been investigated with the following question: 'How many slices of bread do you usually eat daily? (Mark 0 if you do not eat bread) 1. dark rye bread _ slices, 2. graham, whole grain wheat bread _ slices, 3. white bread _ slices'.

The time trends of bread consumption were first described as slices per day using three-year moving averages. Since the distribution of the bread variables was skewed to the left (skewness: rye 2.52, whole-grain 6.21, white 6.89) and the proportions of non-users of wholegrain bread (32\%) and white bread (76\%) were high, the continuous variables were dichotomised into categories of 'high' and 'low' users. The prevalence of high consumption of each bread type was analysed with logistic regression models ${ }^{22}$. All the models were fit separately to males and females and the main effects were included in their temporal order. The overall effect was 
added first, followed by time period, age, education and place of residence. In order to assess the stability of the individual-level relationships over time, the interactions of period with age, education and urbanisation were included separately into the 'fully' adjusted main effects models. As the analysis of annual mean consumption did not show any natural periods, the data were classified into four easily interpretable periods: 1978-1984, 1985-1989, 1990-1994 and 1995-1998. The statistical significance of the terms was assessed using scaled deviance and the change in the degrees of freedom ( $\Delta \mathrm{SD}$ and $\Delta \mathrm{DF}$ ). Results of the unadjusted and 'fully' adjusted models are presented in odds ratios (OR) and 95\% confidence intervals (CI).

The prevalence of daily smoking was estimated using an index comprised of several questions inquiring about the duration of smoking and the current smoking status ${ }^{23}$. The form of the question on vegetable consumption was: 'How often during the last week have you eaten fresh vegetables?: 1 . never, 2 . on 1-2 days, 3 . on 3-5 days, 4 . on 6-7 days'. Leisure-time physical activity was evaluated in a similar way: 'How often do you do physical exercise during your leisure time at least 30 minutes making you at least mildly short of breath or perspire?'. Alcohol consumption was evaluated with the question: 'How many glasses (regular restaurant portions) or bottles of the following drinks have you had during the last week ( 7 days)?: medium strong or strong beer, free mixed highballs, strong alcohol/spirits, wine or the equivalent'.

The association of bread consumption with the four health lifestyle indicators was analysed by comparing the bread consumption of those who follow a healthy lifestyle and those who do not. These habits were dichotomised by using the following cut-off points: non-smoking/daily smoking, fresh vegetables 6-7 times per week/fresh vegetables 5-0 times, exercise at least 3 times per week/ exercise 2-0 times, low alcohol consumption/at least 13 (males) or 5 (females) alcohol portions weekly. The bread consumption ratios were calculated in all subgroups of the background variables by dividing the mean consumption of the 'healthy' group by the mean consumption of the 'unhealthy' group. In addition, three-year moving averages for these ratios of each age, education and urbanisation group were analysed. No systematic changes emerged in the ratios over time so they are not presented.
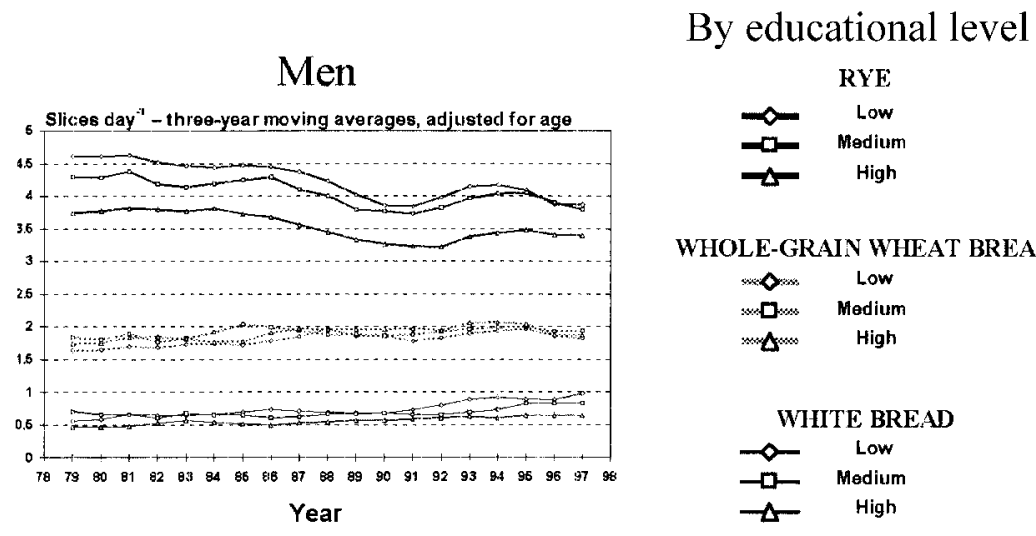

WHOLE-GRAIN WHEAT BREAD
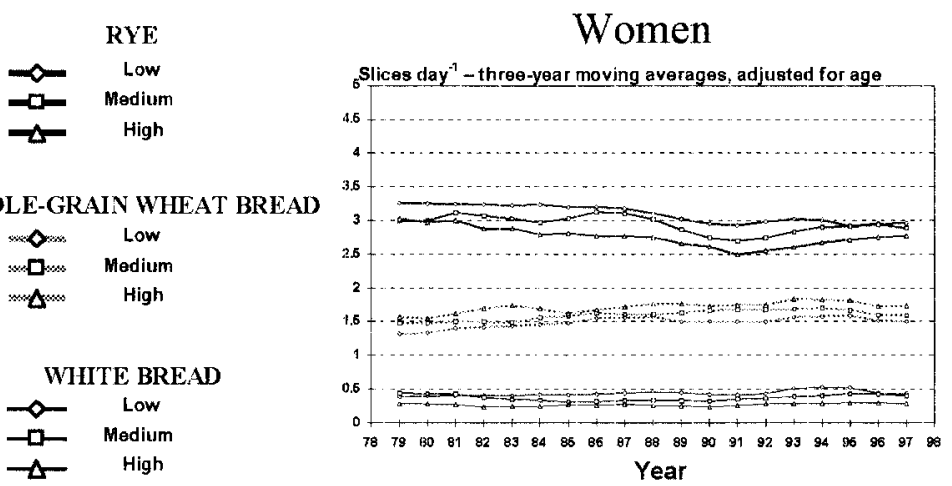

By place of residence

Men

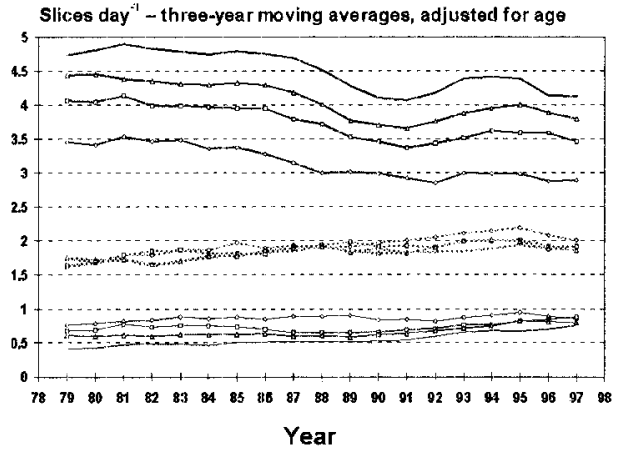

RYE

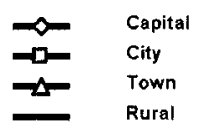

WHOLE-GRAIV WHEAT BREAD

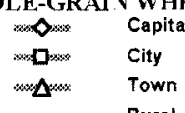

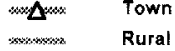

WHTE BREAD

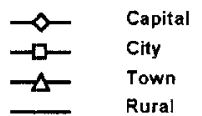

Women

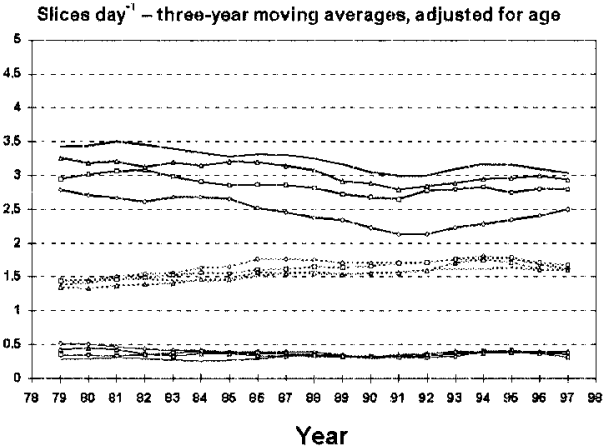

Fig. 1 Consumption of different bread types by educational level and place of residence 
Table 2 Background of bread consumption, OR values of logistic regression models

\begin{tabular}{|c|c|c|c|c|c|c|c|c|c|}
\hline \multirow{3}{*}{$\begin{array}{l}\text { MEN } \\
\text { Total prevalence (\%) }\end{array}$} & \multicolumn{3}{|c|}{ Rye bread use $>6$ pieces day ${ }^{-1}$} & \multicolumn{3}{|c|}{ Whole-grain wheat bread use $>3$ pieces day ${ }^{-1}$} & \multicolumn{3}{|c|}{ White bread use $>1$ piece day ${ }^{-1}$} \\
\hline & \multicolumn{3}{|c|}{24} & \multicolumn{3}{|c|}{26} & \multicolumn{3}{|c|}{29} \\
\hline & Unadjusted & Adjusted* $^{*}$ & $(95 \% \mathrm{Cl})$ & Unadjusted & Adjusted* $^{*}$ & $(95 \% \mathrm{Cl})$ & Unadjusted & Adjusted $^{*}$ & $(95 \% \mathrm{Cl})$ \\
\hline \multicolumn{10}{|l|}{ Study period } \\
\hline 1978-84 & 1.00 & 1.00 & & 1.00 & 1.00 & & 1.00 & 1.00 & \\
\hline $1985-89$ & 0.90 & 0.94 & $(0.88-1.01)$ & 1.17 & 1.18 & $(1.10-1.26)$ & 1.08 & 1.07 & $(1.00-1.15)$ \\
\hline 1990-94 & 0.67 & 0.74 & (0.69-0.79) & 1.23 & 1.23 & $(1.15-1.31)$ & 1.19 & 1.18 & $(1.11-1.26)$ \\
\hline 1995-98 & 0.68 & 0.80 & $(0.74-0.86)$ & 1.22 & 1.22 & $(1.13-1.31)$ & 1.32 & 1.33 & $(1.24-1.43)$ \\
\hline \multicolumn{10}{|l|}{ Age group } \\
\hline $20-34$ years & 1.00 & 1.00 & & 1.00 & 1.00 & & 1.00 & 1.00 & \\
\hline $35-49$ years & 1.00 & 0.92 & $(0.86-0.97)$ & 1.00 & 0.99 & $(0.93-1.05)$ & 0.75 & 0.76 & $(0.71-0.80)$ \\
\hline $50-64$ years & 1.05 & 0.85 & $(0.79-0.91)$ & 0.98 & 0.97 & $(0.91-1.04)$ & 0.55 & 0.56 & $(0.52-0.60)$ \\
\hline \multicolumn{10}{|l|}{ Education group } \\
\hline $0-9$ years & 1.00 & 1.00 & & 1.00 & 1.00 & & 1.00 & 1.00 & \\
\hline $10-12$ years & 0.78 & 0.81 & $(0.76-0.87)$ & 1.04 & 0.99 & $(0.93-1.06)$ & 1.45 & 1.12 & $(1.05-1.19)$ \\
\hline $13+$ years & 0.49 & 0.56 & $(0.52-0.60)$ & 1.04 & 1.00 & $(0.93-1.07)$ & 1.32 & 0.96 & $(0.90-1.03)$ \\
\hline \multicolumn{10}{|l|}{ Place of residence } \\
\hline Capital region & 1.00 & 1.00 & & 1.00 & 1.00 & & 1.00 & 1.00 & \\
\hline Cities & 1.47 & 1.37 & $(1.24-1.52)$ & 0.99 & 0.99 & $(0.91-1.08)$ & 0.87 & 0.87 & $(0.80-0.94)$ \\
\hline Towns & 1.96 & 1.79 & $(1.62-1.97)$ & 0.99 & 1.00 & $(0.92-1.08)$ & 0.76 & 0.76 & $(0.70-0.82)$ \\
\hline Rural & 2.86 & 2.50 & $(2.29-2.73)$ & 0.99 & 1.00 & $(0.93-1.08)$ & 0.60 & 0.61 & $(0.57-0.66)$ \\
\hline WOMEN & \multicolumn{3}{|c|}{ Rye bread use $>5$ pieces day ${ }^{-1}$} & \multicolumn{3}{|c|}{ Whole-grain wheat bread use $>3$ pieces day ${ }^{-1}$} & \multicolumn{3}{|c|}{ White bread use $>1$ piece day ${ }^{-1}$} \\
\hline \multirow[t]{2}{*}{ Total prevalence (\%) } & \multicolumn{3}{|c|}{17} & \multicolumn{3}{|c|}{19} & \multicolumn{3}{|c|}{20} \\
\hline & Unadjusted & Adjusted* & $(95 \% \mathrm{Cl})$ & Unadjusted & Adjusted* $^{*}$ & $(95 \% \mathrm{Cl})$ & Unadjusted & Adjusted* $^{*}$ & $(95 \% \mathrm{Cl})$ \\
\hline \multicolumn{10}{|l|}{ Study period } \\
\hline 1978-84 & 1.00 & 1.00 & & 1.00 & 1.00 & & 1.00 & 1.00 & \\
\hline $1985-89$ & 0.99 & 1.01 & $(0.94-1.09)$ & 1.28 & 1.26 & $(1.17-1.35)$ & 1.01 & 1.03 & $(0.96-1.11)$ \\
\hline $1990-94$ & 0.78 & 0.82 & $(0.76-0.89)$ & 1.33 & 1.27 & (1.18-1.37) & 1.00 & 1.07 & $(0.99-1.15)$ \\
\hline $1995-98$ & 0.95 & 1.04 & $(0.96-1.13)$ & 1.32 & 1.24 & (1.15-1.35) & 1.00 & 1.10 & $(1.01-1.20)$ \\
\hline \multicolumn{10}{|l|}{ Age group } \\
\hline 20-34 years & 1.00 & 1.00 & & 1.00 & 1.00 & & 1.00 & 1.00 & \\
\hline $35-49$ years & 1.28 & 1.19 & $(1.11-1.28)$ & 1.12 & 1.16 & $(1.08-1.24)$ & 0.68 & 0.63 & $(0.59-0.68)$ \\
\hline $50-64$ years & 1.33 & 1.12 & $(1.03-1.21)$ & 1.17 & 1.31 & $(1.21-1.41)$ & 0.57 & 0.50 & $(0.46-0.54)$ \\
\hline \multicolumn{10}{|l|}{ Education group } \\
\hline $0-9$ years & 1.00 & 1.00 & & 1.00 & 1.00 & & 1.00 & 1.00 & \\
\hline $10-12$ years & 0.78 & 0.84 & $(0.78-0.91)$ & 1.04 & 1.08 & $(1.01-1.17)$ & 1.19 & 0.94 & $(0.87-1.01)$ \\
\hline $13+$ years & 0.64 & 0.75 & $(0.70-0.81)$ & 1.20 & 1.26 & $(1.17-1.35)$ & 1.01 & 0.72 & $(0.66-0.77)$ \\
\hline \multicolumn{10}{|l|}{ Place of residence } \\
\hline Capital region & 1.00 & 1.00 & & 1.00 & 1.00 & & 1.00 & 1.00 & \\
\hline Cities & 1.61 & 1.58 & $(1.42-1.75)$ & 0.87 & 0.89 & $(0.82-0.97)$ & 0.94 & 0.92 & $(0.85-1.00)$ \\
\hline Towns & 2.02 & 1.94 & $(1.75-2.14)$ & 0.81 & 0.84 & $(0.77-0.91)$ & 0.92 & 0.90 & $(0.82-0.98)$ \\
\hline Rural & 2.52 & 2.38 & $(2.16-2.62)$ & 0.83 & 0.86 & $(0.80-0.93)$ & 0.81 & 0.79 & $(0.73-0.86)$ \\
\hline
\end{tabular}

${ }^{*}$ Adjusted for all other terms of the model.

\section{Results}

The males consistently consumed more bread than did females. The consumption of white bread was lower than that of rye bread and the level of whole-grain bread consumption was in between. The consumption of rye bread was consistently higher for the less educated and rural people (Fig. 1).

The high consumption of rye bread was associated with time period, education and place of residence $(P<$ 0.001). Among the females, consumption was also associated with age $(P<0.001)$. The overall prevalence of high consumption decreased over time, but during the last period, a slight increase appeared among the females. In general, high consumption was more prevalent for the less educated and rural people (Table 2). In the first two periods, high consumption was most prevalent and in the last two periods least prevalent in the youngest male age group. In addition, for the females, the age differences changed similarly, the youngest becoming the group with the lowest prevalence (interaction of time period and age, $P<0.001)$.

Among males, whole-grain bread consumption was associated with time period only, but among the females with all of the main effects $(P<0.001)$. The prevalence of high consumption increased between the first and second periods, but remained constant thereafter. High consumption was more prevalent for the older, more educated and urban females (Table 2).

White bread consumption was associated with all of the 
Table 3 Comparison of bread consumption in 'healthy' and 'unhealthy' lifestyle groups

\begin{tabular}{|c|c|c|c|c|c|c|c|c|c|c|c|c|c|c|c|c|c|}
\hline \multirow[t]{2}{*}{ MEN } & \multirow[b]{2}{*}{$N$} & \multicolumn{4}{|c|}{ Non-smoking } & \multicolumn{4}{|c|}{ Daily use of fresh vegetables } & \multicolumn{4}{|c|}{ Frequent physical exercise } & \multicolumn{4}{|c|}{ Moderate alcohol consumption } \\
\hline & & $\%$ & ryeR $^{\star}$ & whoR $^{\star}$ & whiR $^{*}$ & $\%$ & ryeR $^{*}$ & whoR $^{\star}$ & whiR $^{*}$ & $\%$ & ryeR* & whoR $^{\star}$ & whiR $^{\star}$ & $\%$ & ryeR $^{*}$ & whoR $^{\star}$ & whiR $^{\star}$ \\
\hline \multicolumn{18}{|l|}{ Study period } \\
\hline 1978-84 & 15,384 & 66 & 1.01 & 1.03 & 0.73 & 17 & 0.92 & 1.11 & 0.75 & 46 & 1.02 & 1.01 & 1.02 & 84 & 1.10 & 1.05 & 0.73 \\
\hline $1985-89$ & 9149 & 67 & 0.99 & 1.07 & 0.70 & 21 & 0.93 & 1.19 & 0.74 & 49 & 1.07 & 1.02 & 0.89 & 83 & 1.10 & 1.01 & 0.75 \\
\hline 1990-94 & 8606 & 69 & 1.00 & 1.07 & 0.69 & 25 & 0.95 & 1.19 & 0.75 & 55 & 1.07 & 1.01 & 0.95 & 79 & 1.08 & 1.01 & 0.76 \\
\hline 1995-98 & 6634 & 71 & 1.01 & 0.97 & 0.63 & 27 & 1.03 & 1.09 & 0.73 & 60 & 1.13 & 1.04 & 0.84 & 77 & 1.08 & 0.99 & 0.74 \\
\hline \multicolumn{18}{|l|}{ Age group } \\
\hline $20-34$ years & 13,038 & 62 & 1.00 & 1.01 & 0.64 & 21 & 0.96 & 1.14 & 0.77 & 48 & 1.08 & 1.04 & 0.90 & 78 & 1.09 & 0.95 & 0.68 \\
\hline $35-49$ years & 13,089 & 65 & 1.01 & 1.07 & 0.68 & 25 & 0.90 & 1.17 & 0.76 & 45 & 1.04 & 1.03 & 0.86 & 76 & 1.11 & 1.04 & 0.77 \\
\hline $50-64$ years & 9999 & 73 & 1.00 & 1.11 & 0.80 & 21 & 0.93 & 1.16 & 0.78 & 56 & 1.02 & 0.95 & 0.90 & 86 & 1.15 & 1.05 & 0.72 \\
\hline \multicolumn{18}{|l|}{ Education group } \\
\hline $0-9$ years & 17,062 & 66 & 1.01 & 1.06 & 0.71 & 15 & 0.96 & 1.18 & 0.80 & 49 & 1.01 & 0.98 & 1.00 & 85 & 1.07 & 1.00 & 0.72 \\
\hline $10-12$ years & 12,138 & 65 & 1.01 & 1.03 & 0.69 & 21 & 0.98 & 1.13 & 0.75 & 52 & 1.07 & 1.09 & 0.96 & 79 & 1.08 & 1.01 & 0.71 \\
\hline $13+$ years & 9937 & 74 & 1.01 & 1.05 & 0.71 & 36 & 0.98 & 1.13 & 0.77 & 53 & 1.11 & 1.02 & 0.86 & 75 & 1.09 & 1.02 & 0.79 \\
\hline \multicolumn{18}{|c|}{ Place of residence } \\
\hline Capital region & 5929 & 66 & 1.01 & 1.09 & 0.73 & 32 & 1.01 & 1.16 & 0.62 & 52 & 1.11 & 1.05 & 0.91 & 72 & 1.12 & 1.06 & 0.85 \\
\hline Cities & 8070 & 67 & 0.97 & 1.08 & 0.70 & 24 & 0.99 & 1.14 & 0.72 & 53 & 1.09 & 1.06 & 0.88 & 78 & 1.05 & 1.06 & 0.76 \\
\hline Towns & 9600 & 67 & 1.01 & 1.05 & 0.66 & 21 & 0.99 & 1.14 & 0.68 & 52 & 1.05 & 1.02 & 0.97 & 81 & 1,03 & 1.00 & 0.77 \\
\hline Rural & 16,154 & 69 & 0.99 & 1.01 & 0.72 & 18 & 0.93 & 1.16 & 0.86 & 48 & 1.03 & 1.00 & 0.98 & 85 & 1.07 & 0.96 & 0.71 \\
\hline \multirow[t]{2}{*}{ WOMEN } & & \multicolumn{4}{|c|}{ Non-smoking } & \multicolumn{4}{|c|}{ Daily use of fresh vegetables } & \multicolumn{4}{|c|}{ Frequent physical exercise } & \multicolumn{4}{|c|}{ Moderate alcohol consumption } \\
\hline & $N$ & $\%$ & ryeR $^{\star}$ & whoR $^{\star}$ & whiR $^{*}$ & $\%$ & ryeR $^{*}$ & whoR $^{\star}$ & whiR $^{\star}$ & $\%$ & ryeR $^{*}$ & whoR $^{\star}$ & whiR $^{\star}$ & $\%$ & ryeR $^{*}$ & whoR* & whiR* $^{\star}$ \\
\hline \multicolumn{18}{|l|}{ Study period } \\
\hline 1978-84 & 15,272 & 83 & 1.06 & 1.19 & 0.71 & 25 & 0.94 & 1.15 & 0.75 & 44 & 1.03 & 0.95 & 0.81 & 86 & 1.12 & 1.08 & 0.71 \\
\hline $1985-89$ & 10,163 & 81 & 1.07 & 1.16 & 0.70 & 31 & 0.97 & 1.07 & 0.63 & 49 & 1.05 & 0.98 & 0.77 & 84 & 1.16 & 1.05 & 0.81 \\
\hline 1990-94 & 9702 & 80 & 1.07 & 1.21 & 0.56 & 37 & 0.99 & 1.07 & 0.55 & 56 & 1.11 & 0.97 & 0.85 & 76 & 1.15 & 1.06 & 0.81 \\
\hline 1995-98 & 7628 & 81 & 1.08 & 1.15 & 0.62 & 41 & 1.03 & 1.03 & 0.55 & 62 & 1.10 & 1.02 & 0.78 & 74 & 1.11 & 1.02 & 0.82 \\
\hline \multicolumn{18}{|l|}{ Age group } \\
\hline $20-34$ years & 13,542 & 75 & 1.04 & 1.18 & 0.66 & 31 & 0.99 & 1.13 & 0.62 & 46 & 1.05 & 1.01 & 0.84 & 76 & 1.12 & 1.01 & 0.82 \\
\hline $35-49$ years & 13,545 & 80 & 1.08 & 1.20 & 0.68 & 38 & 0.94 & 1.09 & 0.73 & 49 & 1.05 & 0.96 & 0.66 & 76 & 1.16 & 1.07 & 0.81 \\
\hline $50-64$ years & 11,654 & 90 & 1.04 & 1.20 & 0.68 & 30 & 0.94 & 1.06 & 0.55 & 58 & 1.03 & 0.97 & 0.79 & 88 & 1.12 & 1.03 & 0.92 \\
\hline \multicolumn{18}{|c|}{ Education group } \\
\hline $0-9$ years & 16,645 & 82 & 1.06 & 1.16 & 0.69 & 22 & 0.97 & 1.07 & 0.76 & 53 & 1.02 & 0.99 & 0.85 & 87 & 1.13 & 1.04 & 0.67 \\
\hline $10-12$ years & 12,700 & 77 & 1.11 & 1.14 & 0.64 & 32 & 1.02 & 1.06 & 0.59 & 51 & 1.06 & 0.98 & 0.82 & 78 & 1.10 & 1.04 & 0.76 \\
\hline $13+$ years & 12,710 & 84 & 1.05 & 1.22 & 0.65 & 45 & 1.00 & 1.08 & 0.60 & 49 & 1.07 & 1.00 & 0.74 & 73 & 1.14 & 1.08 & 0.86 \\
\hline \multicolumn{18}{|c|}{ Place of residence } \\
\hline Capital region & 7287 & 75 & 1.02 & 1.21 & 0.68 & 44 & 1.04 & 1.03 & 0.55 & 48 & 1.05 & 1.01 & 0.75 & 68 & 1.09 & 1.12 & 0.90 \\
\hline Cities & 9325 & 80 & 1.05 & 1.21 & 0.66 & 34 & 0.99 & 1.13 & 0.51 & 51 & 1.05 & 1.03 & 0.82 & 78 & 1.10 & 1.09 & 0.86 \\
\hline Towns & 10,178 & 81 & 1.04 & 1.20 & 0.66 & 31 & 0.99 & 1.10 & 0.58 & 52 & 1.05 & 0.99 & 0.86 & 81 & 1.10 & 0.99 & 0.81 \\
\hline Rural & 15,958 & 85 & 1.08 & 1.14 & 0.63 & 27 & 0.97 & 1.10 & 0.78 & 52 & 1.04 & 0.96 & 0.82 & 85 & 1.14 & 1.01 & 0.69 \\
\hline
\end{tabular}

* ryeR (rye bread), whoR (whole-grain wheat bread), whiR (white bread)=mean of bread use in 'healthy' group/mean of bread use in 'unhealthy' group.

main effects $(P<0.001)$. The overall prevalence increased over time, especially among the males. Consumption was more prevalent by the younger, less educated and urban people. Among the males, however, the use was most prevalent in the 'medium' education group and the difference between the lowest and highest education groups was not statistically significant (Table 2). The urbanisation differences among the males remained rather constant during the three first periods; the prevalence was highest in the capital region. However, during the last period, differences diminished (interaction of period and place of residence, $P<$ 0.001). The difference between the youngest and other age groups increased for the females (interaction of period and age, $P<0.001$ ). During the first period, the prevalence was clearly highest in the capital region, but during the last two periods, very little difference emerged for the females living in the urban and rural areas (interaction of period and place of residence, $P<0.001)$.

Rye bread consumption was not associated with smoking. On the other hand, smokers ate more white bread than non-smokers. Similarly, the consumption of rye bread was not associated with the frequent consumption of vegetables, but the consumption of white bread was associated with a low consumption of vegetables in all subgroups. Rye bread consumption did not vary systematically with physical exercise, but females who exercised less used more white bread. Among the more educated, the consumption of white bread was lower for frequent exercisers, whereas in the lowest educational group, the association was weaker. Moderate alcohol consumption was related to bread consumption, as were all of the other indicators. The consumption of rye bread 
was slightly more common and the consumption of white bread was less common for moderate drinkers. The use of whole-grain bread was not systematically associated with healthy lifestyles (Table 3).

\section{Discussion}

Our results are well in line with previous Finnish studies which suggest that the consumption of rye bread has decreased and that rye bread is eaten more than white bread $^{4,17-19}$. Furthermore, our results on socio-economic and regional differences in bread consumption are in accordance with previous Finnish studies ${ }^{8,11,19}$. Even though our questionnaire did not measure bread consumption quantitatively in grams, the study is nevertheless reliable in analysing trends and variation in bread consumption.

Previous studies have not analysed the time trends of bread consumption in different population groups. Our data showed that, for females, the decrease of rye bread consumption reversed in trend to a slow increase in the 1990s. As for the males, the decrease seemed to level off. The increasing rye bread consumption, especially among urban females, can probably be explained by availability. Traditionally, Finnish rye bread has mostly been sold as large loafs, which are not currently practical for small households preferring fresh bread. During the 1990s, several new, small rye bread package types appeared on the Finnish market.

Rye bread consumption was consistently associated with a low educational level and a rural place of residence. The use of white bread was also associated with a low educational level, but, contrary to rye bread, white bread consumption correlated with an urban place of residence. The socio-economic pattern of bread consumption in Finland is different when compared with the observations from other western European countries $^{24}$. For example, Hupkens et $a l^{5}{ }^{5}$ showed in a study comparing food habits in Maastricht, Liege and Aachen, that bread consumption in general correlated with a low social status, whereas the use of high-fibre bread increased with increasing social status.

Furthermore, unlike the consumption of white bread, the use of rye bread was not associated with smoking, exercise or alcohol consumption. Recently, Johansson et $a l^{25}$ have shown that the fibre intake of Norwegians correlated positively with a high educational level, nonsmoking and frequent physical exercise, as well as with concern with maintaining a healthy diet. Our results on rye bread - the most important source of dietary fibre in Finland - deviate from the Norwegian findings.

Instead, our results suggest that the recent public discussion on the high fibre content of rye has not changed the traditional place of rye bread in the Finnish dietary pattern. The observed association of white bread with an unhealthy lifestyle seems to be better in line with the current discussion of health-related issues. Those Finns who are concerned about their health avoid white bread but do not seem to associate rye bread with a healthier lifestyle. In Finland rye bread maintains an image that is different from that of whole-grain or dark brown bread in many other western European countries.

\section{Acknowledgements}

This study was carried out in connection of the project 'Rukiin funktionaaliset ominaisuudet' in collaboration with VTT Biotechnology and Food Research and with the University of Kuopio. The financial suppport of Fazer Bakeries and Cultor Baking/Vaasan leipomot is gratefully acknowledged.

\section{References}

1 Pietinen $\mathrm{P}$, Rimm EB, Korhonen $\mathrm{P}$, et al. Intake of dietary fiber and risk of coronary heart disease in a cohort of Finnish men, The Alpha-Tocopherol, Beta-Carotene Cancer Prevention Study. Circulation 1996; 94: 2720-7.

2 ECP Consensus Panel on Cereals and Cancer. Consensus meeting on cereals, fiber, and colorectal and breast cancers. Eur. J. Cancer Prev. 1997; 6: 512-4.

3 Zhang J-X, Hallmans G, Landström M, et al. Soy and rye inhibit the development of Dunning R3327 prostatic adenocarcinoma in rats. Cancer Lett. 1997; 114: 313-4.

4 National Public Health Institute. The 1997 Dietary Survey of Finnish Adults. Helsinki: National Public Health Institute, 1998.

5 Hupkens C, Knibbe R, Drop M. Social class differences in women's fat and fibre consumption. A cross-national study. Appetite 1997; 28: 131-49.

6 Blaxter M. Health and Lifestyles. London and New York: Tavistock/Routledge, 1990; 113-46.

7 Mennell S, Murcott A, van Otterloo A. The Sociology of Food: Eating, Diet and Culture. London: Sage Publications, 1992 54-5.

8 Roos E. Social patterning of food behaviour among Finnish men and women. Doctoral Dissertation. Helsinki: National Public Health Institute, 1998.

9 Statens ernaeringsråd. Norkost 1993-94. Landsomfattende kostholdsundersokelse blant menn og kvinner i alderen 1679 år [National Dietary Survey among 16-79-year-old Men and Women; in Norwegian]. Oslo: Statens ernaeringsråd, 1997.

10 Kleemola P, Roos E, Pietinen P. Dietary changes by the level of education. Sosiaalilääketieteellinen Aikakauslebti 1996; 33: 9-16 [in Finnish with English abstract].

11 Roos E, Prättälä R, Lahelma E, Kleemola P, Pietinen P. Modern and healthy?: socioeconomic differences in the quality of diet. Eur. J. Clin. Nutr. 1996; 50: 753-60.

12 Karisto A, Prättälä R, Berg M-A. The good, the bad and the ugly. Differences and changes in health related lifestyles. In: Kjaernes U, Holm L, Ekström M, Fürst E, Prättälä R, eds. Regulating Markets - Regulating People. On Food and Nutrition Policy. Oslo: Novus Press, 1993; 185-204.

13 Hulshof K, Löwik M, Kok F, Wedel M, Brants A, Hermus R, ten Hoor F. Diet and other life-style factors in different socioeconomic groups. Eur. J. Clin. Nutr. 1991; 45: 441-50.

14 Lahelma E, Rahkonen O, Berg M-A, Helakorpi S, Prättälä R, Puska P, Uutela A. Changes in health status and health behaviour among Finnish adults 1978-1993. Scand. J. Work Environ. Health 1997; 23(Suppl. 3): 85-90. 
15 Laurila E. Consumption in Finnish Economy in the Years 1900-1975. Helsinki: The Research Institute of the Finnish Economy, 1985; 117 [in Finnish].

16 Roine P. The amounts and adequacy of food rations in Finland during 1941-46. Maataloustieteellinen Aikakauskirja 1948; 9: 8-9.

17 Finnish Ministry of Forestry and Agriculture. Food Balance Sheets 1997 [Online]. Available at http://www.mmm.fi/tike.

18 Uusitalo U, Pietinen P, Leino U. Food and Nutrient Intake among Adults in East and Southwest Finland - A Dietary Survey of the Finmonica Project in 1982. Helsinki: National Public Health Institute, 1987.

19 Kleemola P, Virtanen M, Pietinen P. The 1992 Dietary Survey of Finnish Adults. Helsinki: National Public Health Institute, 1994.

20 Helasoja V. Postikyselyaineiston ulkoisesta luotettavuudesta, Aikuisväestön terveyskäyttäyminen -tutkimuksen vastaajajoukon edustavuus ja alkoholinkulutustietojen yleistettävyys [The external validity of a postal survey, the representative- ness and feasibility of alcohol consumption information of AVTK survey]. Unpublished Master's Thesis. Helsinki: University of Helsinki, 1998 [in Finnish].

21 Prättälä R, Helasoja V, and the FINBALT group. FINBALT HEALTH MONITOR - Feasibility of a Collaborative System for Monitoring Health Behaviour in Finland and the Baltic Countries. Helsinki: National Public Health Institute, 1999.

22 SPSS, Inc. SPSS Reference Guide. Chicago, IL: SPSS Inc., 1990.

23 Helakorpi S, Uutela A, Prättälä R, Puska P. Health Behaviour among Finnish Adult Population, Spring 1999. Helsinki: National Public Health Institute, 1999.

24 Prevost AT, Whichelow MJ, Cox BD. Longitudinal dietary changes between 1984-5 and 1991-2 in British adults: association with socio-demographic, lifestyle and health factors. Br. J. Nutr. 1997; 78: 873-88.

25 Johansson L, Thelle D, Solvoll K, Bjoerneboe, Drevon Ch. Healthy dietary habits in relation social determinants and lifestyle factors. Br. J. Nutr. 1999; 81: 211-20. 